\title{
Case report on Cotard's syndrome (CS) in a patient with schizophrenia: a rare case from Malaysia
}

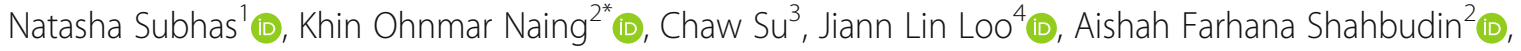 \\ Vevehkanandar Sivasubramaniam ${ }^{1}$ and Reenisha Thyagarajan
}

\begin{abstract}
Background: Cotard's syndrome (CS) is a neuropsychiatric condition marked by nihilistic delusional(s). Due to its rarity, misdiagnosis of the syndrome often occurs. The current case study is of a Malaysian woman who was misdiagnosed for several years by professionals due to the presence of hypochondriac symptoms before receiving the correct diagnosis.

Case presentation: In this case presentation, we describe the case of L, a 42-year-old Malaysian lady who was first misdiagnosed with depression. The diagnosis of schizophrenia and CS was confirmed after thorough clinical examination, diagnostic investigations, and deliberation at a departmental forum. The patient improved after receiving electroconvulsive therapy $(E C T)$ along with antipsychotic medications.

Conclusions: This case study highlights the importance of early recognition of CS by professionals as it can save time for both parties when setting up a treatment plan. Essentially, early recognition of CS in schizophrenia is paramount in the process of rapid stabilization through ECT and promotion of patient recovery.
\end{abstract}

Keywords: Cotard's syndrome, Depression, ECT, Hypochondriac, Schizophrenia

\section{Background}

First described in the 1880 s by French neurologist Jules Cotard, Cotard's syndrome (CS) is a form of monothematic delusion characterized by beliefs that one's own body or life is nonexistent (nihilistic beliefs) [1]. Someone with CS may believe that their life does not exist or a certain body part may be dysfunctioning. CS is an illness rarely diagnosed on its own and is not included as a specific disorder in the Diagnostic and Statistical Manual of Mental Disorders (DSM-5) [2, 3]. However, CS is found on a wide spectrum of medical or neuropsychiatric conditions and is alleged to be a manifestation of an underlying illness such as severe depression [3-5].

\footnotetext{
* Correspondence: tnnjkk99@gmail.com

${ }^{2}$ Department of Psychiatry, Faculty of Medicines and Health Sciences, University Putra Malaysia, UPM, 43400 Serdang, Selangor Darul Ehsan, Malaysia

Full list of author information is available at the end of the article
}

Nihilistic delusions due to CS can occur in patients with schizophrenia but its prevalence is rare $(<1 \%)[1$, 6]. Schizophrenia and nihilistic delusions are both related to the loss of sense of inner self, and to date, only seven case reports or series have explored this condition $[1,6,7]$. Therefore, it is a comorbid disorder that is easily misdiagnosed or dismissed by health and mental health professionals due to the presence of hypochondriac symptoms, as in the current case study. Hypochondria refer to a distressing preoccupation or fear about a health issue that someone perceives to have but has yet to be diagnosed [8]. In L's case, physicians first did not believe anything was wrong with her when she complained of various health issues. Later, she was diagnosed with depression and CS was not detected in her until she had a psychotic episode.

The purpose of this paper is to add to the existing knowledge on the subject, raise awareness of the 
disorder, and provide information of a treatment plan that was successfully implemented. To the best of our knowledge, there has not been a similar case of CS published in Malaysia.

\section{Case presentation}

$\mathrm{L}$ was a 42-year-old administrative assistant who presented regularly to general practitioners with various non-specific health ailments (sneezing and vague abdominal pains) after the passing of her father in 2014. Four years later, her overall mental health had deteriorated. She had become withdrawn, anxious, preoccupied, and unable to sleep due to buzzing noises outside her ear. She was also worried that someone was trying to harm her. As a result of lethargy (due to poor sleep) and issues with concentration, L quit her job. She was diagnosed with major depressive disorder by a private psychiatrist and was prescribed agomelatine $25 \mathrm{mg}$ daily, and zolpidem $10 \mathrm{mg}$ daily. An otorhinolaryngologist found no otorhinolaryngological abnormalities upon examination.

L's mental health and insomnia worsened despite 3 weeks of treatment and she incessantly complained that she "felt like a zombie;" attributing it to the antidepressants [9]. Also, she had become convinced that her organs were decaying. She refused to eat and purged to prove that the food she ate was not being digested. This behavior made her extremely weak and lethargic. Furthermore, she was refusing to urinate and defecate as she believed her bowels and bladder were dysfunctional.

Due to significant physical health deterioration, $\mathrm{L}$ was admitted to the public hospital in Klang Valley in September of 2018. By then, she was having third person auditory hallucinations who were commenting on her action(s) and she was becoming paranoid that imaginary strangers were trying to harm her. No other Schneiderian first-rank symptoms were noted. There were no delusions of misidentification either. Both $\mathrm{L}$ and her family did not notice any features of depression, mania, or hypomania. There was an absence of psychiatric illnesses on either side of the family. L repeatedly pinned her anxiety down to her belief that her organs were dying and liquefying inside her. The initial differential diagnosis included major depressive disorder with psychotic features, psychotic disorder due to another medical condition and schizophrenia. Extensive work-up was performed to rule out possible organic causes. Organic causes were ruled out by collecting a history of fever, seizures, connective tissue disorders, illicit drug use, or any neurological deficits suggestive of migraine, stroke, or meningitis. L's investigations showed all parameters were within normal limits. Given her first episode of psychosis with features of Cotard's syndrome (CS), L was given the diagnosis of schizophrenia and CS (Table $1)$.

After L was admitted, it became apparent that $\mathrm{L}$ was unable to make decisions. Therefore, her family was called in. They were provided psychoeducation concerning the disorder(s), how it is usually treated, and what types of treatments were available. After the session, the psychiatrist and the family came to an agreement that $\mathrm{L}$ should stay in the hospital for a while (1-2 weeks) and commence treatment with an atypical antipsychoticrisperidone ( $2 \mathrm{mg}$, twice a day).

$\mathrm{L}$ showed poor response to risperidone and her nihilistic delusions remained while being treated at the hospital. L insisted the nurses assist her to the ward counter each time she walked. Her physical examination was unremarkable and her mental status examination (MSE) showed blunted affect, poverty of speech, apathy, persecutory delusion, and hallucinatory behavior. Her antipsychotic treatment was switched to amisulpride $200 \mathrm{mg}$ nocte given the superiority over risperidone in effect size and lesser weight gain [10].

$\mathrm{L}$ showed marginal improvement with regards to personal hygiene and meals after 2 weeks although $\mathrm{L}$ started to experience parkinsonism at the dose of $600 \mathrm{mg} \mathrm{BD}$, which were counteracted with $2 \mathrm{mg}$ of trihexyphenidyl. There were still residual symptoms of psychosis upon her discharge.

Unfortunately, L was readmitted a week later after several unsuccessful suicidal attempts as she still had the belief that she could not swallow, urinate, and open her bowel due perceived damage to her internal organs. The extrapyramidal side effects of amisulpride were also still present and she was experiencing amenorrhea due to hyperprolactinemia $(316.2 \mathrm{mU} / \mathrm{l})$. A departmental multidisciplinary discussion was conducted and the conclusion was to provide a course of electroconvulsive therapy (ECT) for acute stabilization of suicidal ideation and nihilistic beliefs [11]. Amisulpride was switched to quetiapine immediate release (IR) $100 \mathrm{mg}$ due to its favorable profile for hyperprolactinemia and extrapyramidal symptoms [12, 13]. Consent for treatment was obtained in accordance to the Malaysian Mental Health Act 2001 [14]. L was to be given an acute course of bitemporal ECT consisting of 6 sessions over 2 weeks on alternative days, using the Mecta SpECTrum $5000 \mathrm{M}^{\mathrm{TM}}$ machine (manufactured by Mecta Corporation, United States of America) with a brief pulse width of $1.0 \mathrm{~m} / \mathrm{s}$ $(33 \mathrm{~Hz})$ (Table 2).

After completion of all six sessions of the acute course of ECT, L showed significant improvement. She was discharged after 3 weeks and was directed to take quetiapine IR $400 \mathrm{mg}$ twice daily at home. Three months later, her menstruation returned and her prolactin level normalized. No extrapyramidal symptoms stayed. One-year 
Table 1 Investigations upon admission

\begin{tabular}{|c|c|c|c|c|}
\hline \multirow{2}{*}{$\begin{array}{l}\text { Investigations } \\
\text { Full blood count }\end{array}$} & & \multirow{2}{*}{$\begin{array}{l}\text { September } \mathbf{2 0 1 8} \\
12.7\end{array}$} & \multirow{2}{*}{$\begin{array}{l}\text { Units } \\
\mathrm{g} / \mathrm{dL}\end{array}$} & \multirow{2}{*}{$\frac{\text { Range }}{12.0-15.0}$} \\
\hline & Hemoglobin & & & \\
\hline & Total white count & 7.30 & $10^{9} / \mathrm{L}$ & 4.0-10.0 \\
\hline & Platelet & 307 & $10^{9} / \mathrm{L}$ & $150-410$ \\
\hline & Hematocrit & 38 & $\%$ & $36-46$ \\
\hline \multirow[t]{5}{*}{ Renal profile } & Urea & 3.6 & $\mathrm{mmol} / \mathrm{L}$ & $3.2-8.2$ \\
\hline & Sodium & 135 & $\mathrm{mmol} / \mathrm{L}$ & $132-146$ \\
\hline & Potassium & 4.0 & $\mathrm{mmol} / \mathrm{L}$ & $3.5-5.5$ \\
\hline & Chloride & 102 & $\mathrm{mmol} / \mathrm{L}$ & 99-109 \\
\hline & Creatinine & 57.5 & $\mu \mathrm{mol} / \mathrm{L}$ & $44.2-97.2$ \\
\hline \multirow[t]{7}{*}{ Liver function test } & Total protein & 81 & $g / L$ & $57-82$ \\
\hline & Albumin & 42 & $g / L$ & $34-50$ \\
\hline & Globulin & 38 & $g / L$ & 25-39 \\
\hline & Total bilirubin & 9 & $\mu \mathrm{mol} / \mathrm{L}$ & $5-21$ \\
\hline & Alkaline phosphatase & 54 & $U / L$ & $46-116$ \\
\hline & Alanine transaminase & 24 & $\mathrm{U} / \mathrm{L}$ & $10-49$ \\
\hline & Aspartate aminotransferase & 18 & $U / L$ & $<34$ \\
\hline \multirow[t]{2}{*}{ Thyroid function test } & Thyroid stimulating hormone & 0.70 & $\mathrm{mU} / \mathrm{L}$ & $0.55-4.78$ \\
\hline & Free T4 (thyroxine) & 19.9 & $\mathrm{pmol} / \mathrm{L}$ & $11.5-22.7$ \\
\hline Fasting blood sugar & & 4.0 & $\mathrm{mmol} / \mathrm{L}$ & $<6.1$ \\
\hline \multirow[t]{4}{*}{ Fasting lipid profile } & Cholesterol & 4.62 & $\mathrm{mmol} / \mathrm{L}$ & $<5.18$ \\
\hline & Triglycerides & 1.62 & $\mathrm{mmol} / \mathrm{L}$ & $<1.70$ \\
\hline & High-density lipoprotein & 1.14 & $\mathrm{mmol} / \mathrm{L}$ & $>1.0$ \\
\hline & Low-density lipoprotein & 2.4 & $\mathrm{mmol} / \mathrm{L}$ & $<2.6$ \\
\hline Connective tissue disease & Antinuclear antibodies & Negative & & \\
\hline \multirow[t]{3}{*}{ Viral screening } & HIV antigen/antibody & \multicolumn{3}{|c|}{ Non-reactive (no evidence of HIV infection) } \\
\hline & Hepatitis C antibody & \multicolumn{3}{|l|}{ Non-reactive } \\
\hline & Hepatitis B surface antigen & \multicolumn{3}{|l|}{ Non-reactive } \\
\hline Electrocardiogram & \multicolumn{4}{|l|}{ Sinus rhythm. No ischemic changes. } \\
\hline Urine toxicology & \multicolumn{4}{|c|}{ Negative for opioids, amphetamine, methamphetamine, cannabis, ketamine. } \\
\hline Urine pregnancy test & \multicolumn{4}{|l|}{ Negative } \\
\hline Computerized tomography scan & \multicolumn{4}{|c|}{ No intracranial abnormalities, bleedings, mass effects, or midline shifts } \\
\hline Conclusion & \multicolumn{4}{|c|}{ All investigations parameters were within normal limits } \\
\hline
\end{tabular}

${ }^{a}$ Notes: $g / d l$ grams per deciliter, $L$ liter, \% percentage, $\mathrm{mmol} / \mathrm{L}$ millimoles per liter, $\mu \mathrm{mol} / \mathrm{L}$ micromoles per liter, $U / L$ units per liter, $\mathrm{m} U / \mathrm{L}$ milliunits per liter, $\mathrm{pmol} / \mathrm{L}$ picomoles per liter

post ECT, she was concordant with the treatment plan and she was in full recovery, including regaining her ability to perform instrumental activity of daily living.

\section{Discussion}

Current knowledge of CS is based on case reports and series and there are 328 cases documented worldwide [15, $16]$. Due to the rarity of CS, its nosology remains unclear and is not classified in the International Classification of Diseases (ICD) or the DSM-5 [17]. The prevalence of CS in schizophrenia is rare. In fact, a study by Stompe and Schanda [18] found that only $0.87 \%$ of patients diagnosed with schizophrenia and CS presented with nihilistichypochondriac delusions and a progressive loss of energy. This means that the prevalence of schizophrenia and CS together is less than $1 \%$ in the population [15]. As shown by Huarcaya-Victoria and colleagues' [5] study, the increased risk of self-aggression is reflected by L's second admission due to her selfharm as part of her CS that is associated with schizophrenia. L is most likely suffering from Cotard's syndrome type I. This is a form of CS that is delusional in origin rather than being secondary to and affective disorder [19]. 
Table 2 Acute course of L's electroconvulsive therapy

\begin{tabular}{|c|c|c|c|c|c|}
\hline Session & $\begin{array}{l}\text { Stimulus } \\
\text { dosage }\end{array}$ & Seizure activity & $\begin{array}{l}\text { Electroencephalography } \\
\text { reading }\end{array}$ & Recommendations & Outcome of electroconvulsive therapy \\
\hline \multirow[t]{2}{*}{1} & $4 \%$ & No seizures & No EEG reading & & \multirow{2}{*}{$\begin{array}{l}\text { L still believed that her body was decaying. } \\
\text { However, she was able to consume } 2-3 \\
\text { spoonsful of rice by herself. } \\
\text { Suicidal thoughts were still profound. }\end{array}$} \\
\hline & $8 \%$ & No seizures & No EEG reading & $\begin{array}{l}\text { To increase the } \\
\text { percentage to } 16 \% \text { for } \\
\text { the next ECT }\end{array}$ & \\
\hline \multirow[t]{3}{*}{2} & $16 \%$ & No seizures & No EEG reading & & \multirow{3}{*}{$\begin{array}{l}\text { L's belief of her body decaying was reduced. } \\
\text { Her food intake was increased from } 2-3 \\
\text { spoonsful of rice to half a plate } \\
\text { "My organs are starting to function and I feel } \\
\text { my body is healing." }\end{array}$} \\
\hline & $32 \%$ & Flickering of toes & $\begin{array}{l}\text { Spike activity poorly } \\
\text { defined with slow irregular } \\
\text { waves (subthreshold EEG) }\end{array}$ & & \\
\hline & $48 \%$ & Flickering of toes & Subthreshold EEG & $\begin{array}{l}\text { To increase the } \\
\text { percentage to } 56 \% \text { for } \\
\text { the next ECT }\end{array}$ & \\
\hline \multirow[t]{2}{*}{3} & $56 \%$ & $\begin{array}{l}\text { Flickering of muscles in } \\
\text { lower limbs }\end{array}$ & Subthreshold EEG & & \multirow[t]{2}{*}{$\begin{array}{l}\text { Without prompting, } L \text { was able to finish a } \\
\text { whole plate of rice by herself. }\end{array}$} \\
\hline & $64 \%$ & $\begin{array}{l}\text { Generalized tonic clonic } \\
\text { movement of the } \\
\text { upper and lower limbs } \\
\text { for } 19 \mathrm{~s}\end{array}$ & $\begin{array}{l}\text { EEG showed } \\
\text { suprathreshold } \\
\text { symmetrical waves for } 27 \\
\text { s }\end{array}$ & $\begin{array}{l}\text { To maintain the same } \\
\text { percentage for the next } \\
\text { ECT }\end{array}$ & \\
\hline 4 & $64 \%$ & $\begin{array}{l}\text { Generalized tonic clonic } \\
\text { movement of the } \\
\text { upper and lower limbs } \\
\text { for } 15 \mathrm{~s}\end{array}$ & $\begin{array}{l}\text { EEG showed } \\
\text { suprathreshold } \\
\text { symmetrical waves for } 21 \\
\text { s }\end{array}$ & $\begin{array}{l}\text { To maintain the same } \\
\text { percentage for the next } \\
\text { ECT }\end{array}$ & $\begin{array}{l}\text { In addition to food intake, L's self-care had also } \\
\text { improved. She was able bathe and use the } \\
\text { toilet. } \\
\text { Her beliefs progressed from decaying body to } \\
\text { her internal organs functioning well, her body } \\
\text { felt warm and "there is blood circulation } \\
\text { coming back to my body." } \\
\text { After this round of ECT, subjective feelings of } \\
\text { suicidal thoughts had markedly decreased }\end{array}$ \\
\hline 5 & $64 \%$ & $\begin{array}{l}\text { Generalized tonic clonic } \\
\text { movement of the } \\
\text { upper and lower limbs } \\
\text { for } 14 \mathrm{~s}\end{array}$ & $\begin{array}{l}\text { EEG showed supra- } \\
\text { threshold symmetrical } \\
\text { waves for } 17 \mathrm{~s}\end{array}$ & $\begin{array}{l}\text { To maintain the same } \\
\text { percentage for the next } \\
\text { ECT }\end{array}$ & $\begin{array}{l}\mathrm{L} \text { appeared more cheerful, happy and reactive } \\
\text { to surroundings. She believed her organs had } \\
\text { returned to full functionality. } \\
\text { Decreased suicidal thought was sustained }\end{array}$ \\
\hline \multirow[t]{2}{*}{6} & $64 \%$ & $\begin{array}{l}\text { Flickering of muscles in } \\
\text { upper and lower limbs }\end{array}$ & Subthreshold EEG & & \multirow{2}{*}{$\begin{array}{l}\text { L's appetite had significantly improved. "I feel } \\
\text { alive, I am alive. My organs are fully functioning } \\
\text { now. I am not suicidal anymore." } \\
\text { After this round of ECT-no persecutory } \\
\text { delusion(s), no nihilistic delusions. Activities of } \\
\text { daily living improved. She was no longer } \\
\text { suicidal }\end{array}$} \\
\hline & $75 \%$ & $\begin{array}{l}\text { Generalized tonic clonic } \\
\text { movement of the } \\
\text { upper and lower limbs } \\
\text { for } 15 \mathrm{~s}\end{array}$ & $\begin{array}{l}\text { EEG showed supra- } \\
\text { threshold symmetrical } \\
\text { waves for } 20 \mathrm{~s}\end{array}$ & $\begin{array}{l}\text { This is the last ECT } \\
\text { session. } L \text { completed } 6 \\
\text { sessions of acute } \\
\text { course of ECT }\end{array}$ & \\
\hline
\end{tabular}

Note: Six sessions of ECT were done over 2 weeks on alternative day, ECT electroconvulsive therapy, EEG electroencephalogram, \% percentage, s seconds

CS represents a series of well-defined symptoms which can prevail on its own or comorbid with other psychiatric or neurological disorders [17]. The hypochondriasis that developed into nihilistic delusions led to a diagnosis of CS. As discussed by Tomasetti and colleagues [17], these symptoms evolve into somatic concerns leading to localized bodily sensations (rotting of organs) or global somatosensorial alterations ("I am dead").

Various papers have highlighted that CS can be reported in neurological disorders (stroke, brain tumors, epilepsy, traumatic brain injury, migraine, subdural hemorrhage), psychiatric disorders (major depressive disorder with psychotic or melancholic features, schizophrenic spectrum, bipolar type I and II disorder, catatonia), demyelinating disorders (multiple sclerosis), dementias, movement disorders (Parkinson's disease), autoimmune inflammations and infections affecting the brain (Hashimoto encephalopathy and anti-N-methyl-Daspartate receptors encephalitis), neuroleptic malignant syndrome, or drug intoxications [5, 17]. Due to the fact that $\mathrm{L}$ did not show signs of any of the disorders above, all other differential diagnoses were ruled out. A thorough history was taken along with relevant blood investigations and neuroimaging was completed to rule out neurological disorders.

The diagnosis of schizophrenia was made in lieu of elementary auditory hallucinations followed by third person running commentary and persecutory delusions independent of affective symptoms. Morgado and colleagues [6] postulated that the relationship between CS and schizophrenia could be due to poor flow of information from the sensory cortex of the brain to the limbic system. Schizophrenia appears to effect the nondominant frontal, temporal, and parietal lobes as found 
in patients with CS $[6,11]$, L's deterioration in both her mental and physical function along with her poor response to antidepressants may have been a factor that pushed her toward hospitalization. During her stay at the hospital, L's symptoms improved only after she was given a series of six ECT sessions.

In reports by De Risio and colleagues [20] and Sahoo and Josephs [3], advanced neuroimaging studies showed hyperactivity of the dopamine receptor binding, proving an association between schizophrenia and CS. Sahoo and Josephs [3], also, postulated that using dopamine antagonists would be beneficial in improving psychosis as was done in L's case. Moreover, Debruyne and colleagues [11] highlighted that in patients suffering from CS with a history of hypochondriasis and nihilistic delusions, antipsychotics were more successful than other types of medications. Debruyne and colleagues [11] and Sahoo and Josephs [3] have highlighted ECT as an important form of treatment in CS. In L's case, she showed significant improvement after six ECT sessions. L's symptoms resolved after ECT and she continues to be in remission.

Overall, CS can be viewed as a unique phenomenology on its own. Therefore, although CS is rarely comorbid with schizophrenia and not officially classified in any diagnostic manuals, psychiatrists should be aware of its existence. The knowledge of the disorder can help alleviate the symptoms of many patients who are suffering from this disorder. Additionally, the sharing of cases such as this can help other psychiatrists diagnose and treat patients promptly instead of misdiagnosing and exposing the patient to unwanted side effects of medications. As presented in this study, empirical evidence has shown that the use of antipsychotics and ECT as the treatment of choice for these patients.

\section{Conclusions}

This case study highlights the importance of taking the time to explore a diagnosis not commonly pursued by medical professionals. In checking for symptoms of nihilistic beliefs and taking into account the worsening condition of the patient, it is important that professionals not prematurely dismiss patients who do not fit into common diagnostic criteria. L would have benefitted earlier from proper assessment rather than being dismissed for several years as a hypochondriac. The advantage of non-premature termination may include shortening the length of cognitive and emotional distress felt by the patient. Essentially, early recognition of CS in patients with schizophrenia is paramount in the process of rapid stabilization through medication and ECT in promoting patient recovery.

\section{Abbreviations \\ CS: Cotard's syndrome; CT: Computerized tomography; DSM: Diagnostic and Statistical Manual of Mental Disorders; ECT: Electroconvulsive therapy; EEG: Electroencephalogram; GP: General practitioners; ICD: International Classification of Diseases; IR: Immediate release; MSE: Mental status examination}

\section{Acknowledgements}

The authors would like to thank the Director General of Health, Malaysia, and the patient for their permissions in allowing us to publish this article.

\section{Authors' contributions}

NS, VS, and RT were part of the patient's treating team and conceptualized the case with KON's input. NS drafted the manuscript. KON, CS, JLL, and AFS reviewed and revised the manuscript. CS proofread the manuscript. All authors read and approved the final manuscript.

\section{Funding}

No funding was obtained for this study.

\section{Availability of data and materials}

The data that support the findings of this study are available on request from the corresponding author. The data is not publicly available due to privacy or ethical restrictions.

\section{Declarations}

\section{Ethics approval and consent to participate}

The manuscript was written in accordance with the guidelines of Declaration of Helsinki and written informed consent was obtained from the patient. This case report has been assigned the Research ID: NMRR-21-1130-60409 by the National Medical Research Register (NMRR) of Malaysia on 16 June 2021.

\section{Consent for publication}

Written informed consent was obtained from the patient.

\section{Competing interests}

The authors declared no potential conflicts of interest with respect to the research and authorship of this paper.

\section{Author details}

${ }^{1}$ Department of Psychiatry and Mental Health, Hospital Tengku Ampuan Rahimah, Jalan Langat, 41200 Klang, Selangor Darul Ehsan, Malaysia. 2Department of Psychiatry, Faculty of Medicines and Health Sciences, University Putra Malaysia, UPM, 43400 Serdang, Selangor Darul Ehsan, Malaysia. ${ }^{3}$ Yorkville University, Fredericton, New Brunswick, Canada. ${ }^{4}$ Queensway Clinic, Central and North West London NHS Foundation Trust, 226 Queensway, Bletchley, Milton Keynes MK2 3TE, UK.

Received: 23 February 2021 Accepted: 16 July 2021

Published online: 03 August 2021

\section{References}

1. Bott N, Keller C, Kuppuswamy M, Spelber D, Zeier J. Cotard delusion in the context of schizophrenia: a case report and review of the literature. Front Psychol. 2016;7:1351

2. American Psychiatric Association. Diagnostic and Statistical Manual of Mental Disorders. 5th ed. Arlington: American Psychiatric Publishing; 2013. https://doi.org/10.1176/appi.books.9780890425596.

3. Sahoo A, Josephs KA. A neuropsychiatric analysis of the Cotard delusion. J Neuropsychiatry Clin Neurosci. 2018;30(1):58-65. https://doi.org/10.1176/a ppi.neuropsych.17010018.

4. Grover S, Aneja J, Mahajan S, Varma S. Cotard's syndrome: two case reports and a brief review of literature. J Neurosci Rural Pract. 2014;5(1):S59-62.

5. Huarcaya-Victoria J, Ledesma-Gastañadui M, Huete-Cordova M. Cotard's syndrome in a patient with schizophrenia: case report and review of the literature. Case Rep Psychiatry. 2016;6968409.

6. Morgado P, Ribeiro R, Cerqueira JJ. Cotard symptom without depressive symptoms in a schizophrenic patient. Case Rep Psychiatry. 2015;643191. 
7. Ghaffari-Nejad A, Kerdegari M, Reihani-Kermani H. Self-mutilation of the nose in a schizophrenic patient with Cotard syndrome. Arch Iran Med. 2007; 10(4):540-2.

8. Van den Heuvel OA, Veale D, Stein DJ. Hypochondriasis: considerations for ICD- 11. Rev Bras Psiquiatr. 2014;36(1):21-7. https://doi.org/10.1590/1516-444 6-2013-1218.

9. Gibson K, Cartwright C, Read J. 'In my life antidepressants have been...': qualitative analysis of users' diverse experiences with antidepressants. BMC Psychiatry. 2016;16(1):135. https://doi.org/10.1186/s12888-016-0844-3.

10. Sechter D, Peuskens J, Fleurot O, Rein W, Lecrubier Y. The Amisulpride Study Group. Amisulpride vs. risperidone in chronic schizophrenia: results of a 6 month double-blind study. Neuropsychopharmacology. 2002;27(6): 1071-81. https://doi.org/10.1016/S0893-133X(02)00375-5.

11. Debruyne H, Portzky M, Van den Eynde F, Audenaert K. Cotard's syndrome: a review. Curr Psychiatry Rep. 2009;11(3):197-202. https://doi.org/10.1007/ s11920-009-0031-z

12. Leucht S, Cipriani A, Spineli L, Mavridis D, Örey D, Richter F, et al. Comparative efficacy and tolerability of 15 antipsychotic drugs in schizophrenia: a multiple-treatments meta-analysis. Lancet. 2013;382(9896): 951-62. https://doi.org/10.1016/S0140-6736(13)60733-3.

13. Taylor DM, Barnes TR, Young AH. The Maudsley prescribing guidelines in psychiatry. 13th ed. Hoboken: Wiley; 2018.

14. Khan NN, Yahya Ba, Abu Bakar AK, Ho RC. Malaysian mental health law. BJPsych Int. 2015;12(2):40-2. https://doi.org/10.1192/s2056474000000271.

15. Couto RA, Moreira Gonçalves L. A medical algorithm for Cotard delusion based on more than 300 literature cases. Int J Psychiatry Clin Pract. 2020:113. https://doi.org/10.1080/13651501.2020.1819335.

16. Huarcaya-Victoria J, Bojórquez-De la Torre J, De la Cruz-Oré J. Estructura factorial del Síndrome de Cotard: revisión sistemática de reportes de caso. Rev Colomb Psiquiatr. 2018;49(3):187-93.

17. Tomasetti C, Valchera A, Fornaro M, Vellante F, Orsolini L, Carano A, et al, The 'dead man walking' disorder: an update on Cotard's syndrome. Int Rev Psychiatry. 2020;32(5-6):5000-9.

18. Stompe T, Schanda H. The Cotard symptom in schizophrenic disorders. Neuropsychiatr. 2013;27(1):38-46.

19. Berrios GE, Luque R. Cotard's syndrome: analysis of 100 cases. Acta Psychiatr Scand. 1995:91(3):185-8. https://doi.org/10.1111/j.1600-0447.1995.tb09764.x.

20. De Risio S, De Rossi G, Sarchiapone M, Camardese G, Carli V, Cuomo C, et al. A case of Cotard syndrome: 123I-IBZM SPECT imaging of striatal D2 receptor binding. Psychiatry Res: Neuroimaging. 2004;130(1):109-12. https:// doi.org/10.1016/j.pscychresns.2003.01.001.

\section{Publisher's Note}

Springer Nature remains neutral with regard to jurisdictional claims in published maps and institutional affiliations.

\section{Submit your manuscript to a SpringerOpen ${ }^{\circ}$ journal and benefit from:}

- Convenient online submission

- Rigorous peer review

- Open access: articles freely available online

- High visibility within the field

- Retaining the copyright to your article

Submit your next manuscript at $\boldsymbol{\nabla}$ springeropen.com 